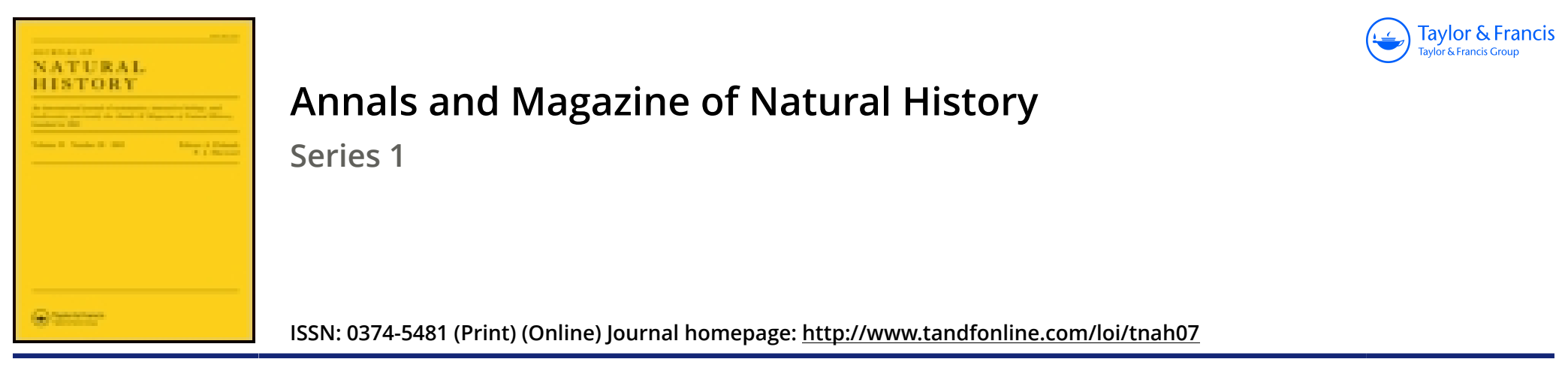

\title{
XXIX.-On the Structure and Affinities of Upupa, Lin., and Irrisor, Lesson
}

\section{H. E. Strickland M.A.}

To cite this article: H. E. Strickland M.A. (1843) XXIX.-On the Structure and Affinities of Upupa, Lin., and Irrisor, Lesson, Annals and Magazine of Natural History, 12:77, 238-243, DOI: 10.1080/03745484309442518

To link to this article: http://dx.doi.org/10.1080/03745484309442518

$$
\text { 册 Published online: } 04 \text { Dec } 2009 .
$$

Submit your article to this journal $\sqsubset \pi$

Q View related articles $\longleftarrow$ 
processes, and with this renarkable difference; that while in the latter the cilia propel the water outwards, sending off a current. at their apices; in the tentacula, on the contrary, the cilia are directed downwards, drawing in and scnding a current of water down their whole surface. This is exactly what we might be led to cxpect in the olfactory organs, and forms a beautiful compensation for the porrer of llawing a curcut of air through the nostrils in the higher animals. Upon the whole, therefore, we think that little doubt can remain of the real function of these organs.

P.S. Since writing the above, we have scen M. Quatrefages' claborate paper on his Eolidina paradoxum in the 'Amnales des Sciences Naturelles,' and arc happy to find that many of his observations agrec with our own. His Eolidina we consider to be undoubtcdly an Eolis very ncarly allied to our E. anyulata, MS., communicated to the last mecting of the $\Lambda$ ssociation.

In the position which he assigns to the amus at the postcrior end of the large central ressel of the gastro-rascular system, wc conceive him to be under a mistake, deceived probably by the apparently abrupt termination of that resscl. The real anus, we have no loubt, will be found at the side, as in other species of this and the allicd gencra.

IIe appears also to have misunderstood tho organs of vision, which, it can scarcely be doubted, are as complete as in other spccics of Eolis, as well as in Polycera, Goniodoris and Melibeca, in all of which a lens is distinctly visible; le however figures and describes the eye in his Eolidina as merely a broad convex cxpansion of the retina and pigmentum nigrum. It would appear from his draxing that he has mistaken the auditory capsulc for the optic ganglion or a swelling of the optic nerve, otherwise he has cutirely orerlooked the organ of hearing. His description of the generative organs is quite at variance with the wellknown peculiarities of this order.

M. Quatrefages' remarks on zoological affinitics are ingenious : on this intcresting portion of the subject however wc camnot at present enter, but hope to do so on a future occasion, when a further investigation of the subject shall have cuabled us to speak witl more certainty than we can possibly do at present.

XXIX.-On the Structure and Affinities of Upupn, Lin., and Irrisor, Lesson. By II. L. Strickiaxd, M.A.*

Tux $\Lambda$ frican continent presents us with sercral species of birds constituting a well-marked genus, to which Isesson in 1831 ap-

- Head to the Zoological Section of the British Association at Cork, $A$ ugust 19,1813 ; and conmminicated by the $\Lambda$ uthor. 
plied the name Irrisor, being a translation of Levaillant's name "Moqucur." 'This group of birds was included by Latham in the genus Upupa, by Shaw in Promerops, by Vicillot in Falcinellus, by Curicr in Mcrops, and by Temminck and Wagler in Epimachus; but as they differ csscntially from the types of all these genera, it is necessary to give them a distinct appellation. Mr. Swainson, Mr. Vigors, the Baron de la Fresnnye, and Mr. G. R. Gray restrict to this group the name Promerops of Brisson; but Brisson was wholly unacquainted with the group before us, and the truc type of his genus Promerops is a totally different bird, called by Vicillot Falcinellus, and by Swainson Pliloturus. It is plain then that the right course is to supplant Falcinellus and Ptiloturus in favour of the old generic name Promerops, and to adopt for the present group the name Irrisor as proposed by MI. Lesson.

Having now settled the nomenclature of this group, I will proceed to spcak of its affinitics, and to slow first its relation to the genus $U_{p u p a}$; and secondly, its position in the general system of Nature.

It should be premised that the genera $U_{p u p a}$ and Irrisor agrec in the form of the beak, but differ in many other particular's. In Upupa the plunage is ferruginous, varich with white and black; the head is crested; the tail moderate and even, composed of ten rectrices; the fect adapted for walking; the lateral tocs being ncarly equal, the cxterior ones divided nearly to their base; thic anterior claws short and blunt, and the hinder claw lengthened and approaching to straightncss. In Irrisor, on the contrary, the plumage is black with rich metallic tints, varicd only with a few white spots on the wings and tail ; the head is not crested; the tail is long and much graduated, composed of twelve rectrices, and the fect are cssentially arboreal, the outer toc being much longer than the inner, and united to the midlle one for the whole length of the basal joint; the lind toc is very long, and all the claws are compressed, sharp, and much curved. It is cvident, therefore, that these birds must differ greatly in their habits; and accordingly we find that the hoopoe lives chicfly on the ground, while the Irrisor is described by I/cvaillant as cxclusively inha. biting trees. 'The question then arises, whether the agreement in the form of their beals is to prepouderate orer the disagreenents of thicir other organs; in other words, whether this rescmblance in the beaks is to be considered as indicating an affinity or only an analogy.

The majority of authors hare classed the Irrisors cither amongst or very near the Hoopocs. But the Baron de la Fresnayc, in the 'Proc. of the Zool. Soc.' for 1840*, p. 12-1, contends that the ge-

* Sce Ann. Nat. Ilist., vol, vii. p.551.-liv. 
nera $U_{p u p a}$ and Irrisor (or as he terms it, Promerops, harc in reality no near affinity to each other. IIe argues that birds hare in many cases been arranged artificially in consequence of anthors being guided solely by the form of the beak without attending to the structure of the other or'gans. $\Lambda \mathrm{fter}$ pointing out the marked differences between the feet. of $U_{p}$ upa and those of Irrisor, he concludes that $U_{p u p a}$ has crident affinities with the larks (Alaudina), but that its true position is in a special family of the ' $T e$ nuirostres, in conjunction with $U_{\text {pucerthia and some other allicd }}$ S. American genera. The genus Irrisor, on the contrary, he considers to belong to the Cimyride, or as they are more correctly called, $N$ ceturiniide, to which they have much rescmblance in their glossy plumage.

Now it is undoubtedly true that the most unnatural classifications of birds have in many cases resulted from the beak being taken as the sole ground of arrangement, to the exclusion of the other organs. I do not howercr think that the juxtaposition of Upupa and Irrisor is really an instance of such a vicious arrangement, and I hope to show, that notwithstanding the disagrecments in their fect, tail and plumage, these two gencra are in reality very closcly allied.

It will generally be found that when screral genera of remote affinity have becn brought together in conscquence of a rescmblance in the form of their beaks, that rescmblance is morc apparent than real, consisting in a general and superficial agreement in the form and outline, while the minor details of structure present differences which at once indiente the true aftinitics of the respective groups. Thus the genus Scythrops was till icrylately classed by all authors among the toucans, on account of the general resemblance of the beak, while if the slightest attention had been paid to the position of the nostrils, it would have been seen at once that its true place is among the cuckoos. A similar superficial resenblance in the beak has caused Tichodroma to be classed with Certhia instead of with Sitta, Spermophila with Pyrr/hula instead of with Guiraca, Oreö̈ca and Falcunculus among the Laniina instead of the Parince, and numerous other cases which might be quoted.

On comparing $U_{p}$ upa with Irrisor, howerer, we find a coincidence of structure not only in the general forms, but in the minutest details of the structure of their beaks; and what is of still greater importance, the benks of these two birds present certain characters which are found in no other group of birds with which I am acquainted.

$U_{p u p a}$ and Irrisor both present to us the remarkable combination of a very long beak with a very short tongue. The two mandibles are for three-quarters of their length perfectly solid, the surfaces of contact being smooth and flat; while in all other 
long-billed birds the interior of both mandibles is provided with a hollow space for the reception and action of a lengthened tonguc, or for the temporary retention of their food. This very reniarkable and peculiar structure has been noticed by no author (as far I am aware) except Wagler, who in his definitions of Upupa and Epimachus, in which last genus he includes Irrisor, notices this character, but without making any comment on its singularity. It is sufficicntly evident from this structure that both $U_{p u p a}$ and Irrisor have very little affinity to the Tenuirostres, in which the tongue is remarkably lengthened and adapted to the purposes of suction, and Irrisor cannot therefore be referred to the Nectariniida, as supposed by the Baron de la Fresnayc. The fact is, that the beaks of these birds are not constructed for suction but for proling, i. e. for reaching into decp holes and crevices in quest of the larre of insects. We know that the hoopoc obtains its food by inserting its beak into the holes made in the ground by coprophagous insects, and it is probable that the Irrisor feeds in a similar manner upon the larre which perforate decayed trees.

The beaks of these tro gencra of birds present another cliaracter unnoticed by all previous author's, and, like the former one, beliered to be peculiar to these two gencra alone. The basal and medial portion of the ridge of both mandibles is obtusely and roundedly carinate, but in procecling towards the apex, the ridgc first becomes flattened, then hollowed, and at last deeply groored. In the Irisor this flattened portion commences in both mandibles about the middle of the beak, and soon changes into a flatbottorned groore, which towards the apex is divided into two by a fine intermediate ridge. In $U_{p u p a}$ the flat space conmences about two-thirds of the total length from the base, and wants the intermediate ridge. With these slight differenees the beals of the two birds may be considered as quite identical in structure,

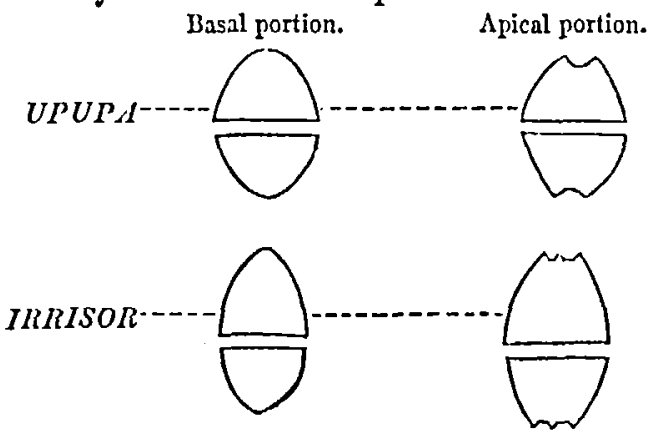

while they differ as before remarkcl from those of all other known birds. These characters are shown in the above figures, which represent maguificd transrerse sections of the mandibles. 
This peculiar coincidence of structure must, I submit, be considercel to indicate something more than mere analogy, and rather to show that $U_{p u p a}$ and Irrisor form two subdivisions of the same superior group; or in other words, that they have more affinity to cach other than either of them has to any other group which it mny rescmble.

Nor are the points of mutual agrecment in these two gencra wholly confined to the structure of the beak. Considernble as their differences undoubtedly are, yet they are not orerpoweringly so. They both nidificate in hollow trees. Thewings in both are similarly formed, the quills being much graduated, and the fourth and fifth longest. The differences in the style of colouring are not greater than we often mect with in gencra of the same subfamily, while the large patchas of white on the remiges and rectrices of $U_{p u p a}$ have their counterparts on the same feathers of Irrisor. The differences in the form of their tails is a character admitted to be only of generic, and in some gencra only of specific importance. The most meighty distinction is undoubtedly to be found in the structure of their fect, but this is not greater than will be found in the fect of many terrestrinl gencra when compared with the arboreal forms of the same families. If we look at the fect of ground-cuckoos, ground-woodpecker's, ground-parrots, or groundpigcons, we shall find that in erery casc these member's arc specially modified to suit the habits of the bird, yet this modification of the fect clocs not blind us to the true affinitics of the species which exhibit it.

It may be said, that in the present case the cvidence of the fect ncutralizes that of the beak, and renders it indifferent which way we decide the question. But this is not a correct vicw of the case, because neither the feet of $U_{p}$ upa nor of rrrisor present any peculiar and unique structure, such as we sce in the beaks of both; they only cxhibit a slight modification of the, same organs adapted for suecial modes of life, and such as are to be met with in many other instances of genera belonging to one and the same sulbfauily.

I conclude, therefore, that the true and natural scries of affinities will be most correctly cxhibited by proserving $U$ jupa and Irrisor in juxtaposition, and by including them both in the family $U_{p u p i d e,}$ which may be divided into two subfamilics, $U_{p u p i n a}$ and Irrisorinc.

We now come to a more difficult question, viz. what is the position of the $U_{p}$ upidac with l'espect to the other families of birds? They certainly are a very insulated group, forming what in gcology would be termed a remote outlier, and it is not casy to say to which of the more continental masses they most nenrly approximate. Guided by the clongration of the beak, the majority of authors have placed them unhesitatingly among the Tenuirostres 
or' suctorial birds; but the latter are distinguishel by the length of the tongue no less than by that of the beak, and this arrangement cannot therefore be called a natural one. Baron de la Fresnaye, while retaining both Irrisor and $U_{p z u}$ a among the Tenuirostres, conncets the latter with $U_{p}$ ucerthia and its allied genera (Cinclodes, Geositta, Limnornis and Furnarius). But these last are merely a subfamily of the great $S . \Lambda$ nacrican family Certhiilla, modificd in accordance with their terrestrial habits, and the rescmblance which they bear to $U_{p u p a}$ is very remote, and scems to be one of analogy only.

Where then are the Upupida to be placed? This question cannot $I$ think be answered satisfactorily till more facts are collected respecting the food, labits and anatomy of this group and of others with which it may be compared. It may howerer be conjectured that they arc allicd in one direction by means of Epimuclius or Astrapia to the Paradiseide, and in amother by Mferops to the Alcellinille, as shown in 'Mnn. Nat. Hist.,' vol. vi. plate 8, and as originally sugercsted by Mr. Vigors in 'Timn. 'Trams.,' vol. xiv. 1.466.. In a third direction they are perhaps conncetcd through Lamprotomis with the Corvide.

XXX.--Upon the Anatomy of Phalangium Opilio (Latr.). By $\Lambda_{\text {LFRED }}$ TULK, M.R.C.S., M.F.S.

[Continued from p. 165.]

[With a I'late.]

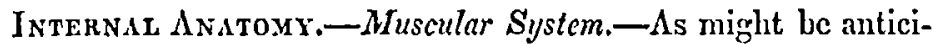
pated from the disproportionate length and slenderness of the extremitics, as contrasted with the body in I'lalangium, and that the latter is clevated and balanced between them during rapid flight, when the creature has often to make its way over an irregular surface of stones and herbage, the muscles required for such exertions are of large size, and constitute by far the most important portion of the class of organs to which they belong. They consist of numcrous strong fasciculi, which arise from the interior of the coxal joints, and pass forwards, filling up the lattcr cavitics almost completely, and are inscrted into the trochanter. The transwerse strice upon them are remarkably distinct and welldefined, and the ultimate fibrils of considerable size, as both the one and the other may be seen under a magnifying power of between thirty and forty lincar. The sarcolemma investing them may bo also perceived, cither raised occasionally from their surface, or connecting their extremities when torn across. The succecding joints of the legs are too small to admit of the precise distribution of the flexors and extcnsors being traced, but by sepa- 